\title{
Paclobutrazol Foliar Sprays to Suppress Growth on Landscape Shrubs
}

\author{
E. Thomas Smiley, Liza Holmes, and Bruce R. Fraedrich
}

\begin{abstract}
This study was conducted to determine the effects of Paclobutrazol (PBZ, Cambistat) foliar sprays on the growth of four shrub species (Abelia $\times$ grandiflora 'Edward Goucher', Ligustrum japonicum 'Rotundifolium', Ligustrum sinense 'Variegatum', Loropetalum chinensis) in the southeastern United States. After the shrubs were established, they were sheared to a defined size and sprayed with $1000 \mathrm{ppm}$ PBZ, $4000 \mathrm{ppm}$ PBZ or left untreated. Paclobutrazol was effective at reducing growth on the four shrub species tested. Total biomass of new leaves and twigs collected 20 weeks after treatment was significantly less with PBZ treatment when compared to the nontreated control in all species except $L$. sinense. There were no differences in biomass that can be attributed to PBZ between the $1000 \mathrm{ppm}$ and $4000 \mathrm{ppm}$ treatments in any species tested. The speed of effectiveness and longevity of this treatment varied with species. In general, the faster growing the shrub species, the greater benefit and the faster the response from spray applications of PBZ. This growth reduction should provide a desirable appearance, less pruning and faster clean up when PBZ is applied to fast growing shrubs.

Key Words. Abelia $\times$ grandiflora 'Edward Goucher'; Bonzi; Cambistat; Ligustrum japonicum 'Rotundifolium'; Ligustrum sinense 'Variegatum'; Loropetalum chinensis; PBZ; Shrub Pruning.
\end{abstract}

Shrub species are planted in the urban landscape to provide understory growth, to act as screens, or for their flower production. While shrubs provide these and other landscape benefits, they often need to be pruned multiple times per year to maintain the size and shape appropriate for the landscape. This requires considerable resources from landscape managers. Therefore, with many fast growing shrub species, it would be desirable if new growth could be suppressed to reduce the number of times the shrubs need to be pruned and to reduce the volume of biomass that needs to be removed in the clean-up process.

Paclobutrazol (PBZ) has been used successfully on trees to suppress growth, especially after utility pruning (Davis 1991; Burch et al. 1996; Bai et al. 2004). One of the major benefits of PBZ application is the reduction in the time required to prune trees following treatment. Time required for utility tree pruning was greatly reduced and highly correlated with the reduction in biomass associated with growth regulator treatment (Burch et al. 1996).

PBZ has been tested and used successfully on turf and fruit crops (Aron et al. 1985; Edgerton 1986; Looney and McKellar 1987). Shrub treatments have been tried, but were limited mainly to soil drench applications on containerized plants (Welker 1986; Joustra 1989; Ruter 1992; Cid and Caballero 1993). Foliar spray treatments of PBZ have been found to change the shape and thickness of some shrub leaves (Martin et al. 1994). Since there may be a substantial delay between the time of soil application of PBZ and growth reduction effects (Bati et al. 2004), spray applications may be more desirable, especially during the first year of a treatment program.

This study was conducted to determine the effects of PBZ foliar sprays on the growth of several landscape shrub species in the southeastern United States.

\section{MATERIALS AND METHODS}

Abelia $\times$ grandiflora 'Edward Goucher', Ligustrum japonicum 'Rotundifolium', Ligustrum sinense 'Variegatum', and Loropetalum chinensis, four fast-growing shrub species commonly planted in the southeastern United States, were selected for testing. Twenty-one plants of each species were planted from 11.3 $\mathrm{L}$ (3 gal) containers into rows spaced $2.4 \mathrm{~m}$ (8 feet) apart with

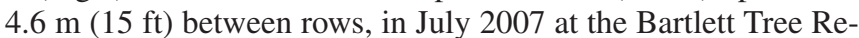
search Laboratory in Charlotte, NC, U.S. (USDA Climate Zone 7). Species were planted within a single row. Fresh wood chip mulch was applied after planting and was maintained to a depth of 5-10 cm (2-4 in) during the trial. Water was provided as necessary using a soaker hose drip irrigation system. Weeds were suppressed with applications of glyphosate, as needed. All plants became established and were growing well by the fall of 2007 .

On May 20, 2008, between 25\% and 33\% of the foliage was pruned from all plants using a Husqvarna HE3 hedge trimmer (Jönköping, Sweden), to provide a baseline size for each plant. This was done by constructing a cubical structure from PVC pipe to define the final shape of the plant and to ensure that growth measurements and re-shearing would be to the same defined area (Figure 1). The structure was removed after shearing. L. chinensis was pruned to a height of $64 \mathrm{~cm}$ (25.25 in) and a width of $60 \mathrm{~cm}$ (23.5 in). All other species were pruned to a height of $33 \mathrm{~cm}$ (13 in) and a width of $47 \mathrm{~cm}(18.5 \mathrm{in})$.

Each species was divided into seven blocks of three plants each. One plant within the block was assigned one of three treatments. Immediately after shearing, a foliar spray treatment was applied uniformly to the point of run-off using a backpack sprayer. Applications included a nonionic spreader sticker (Nufilm ${ }^{\circledR}$ IR, 96\% Poly-1-p-menthene, a terpenic polymer, Miller Chemi- 


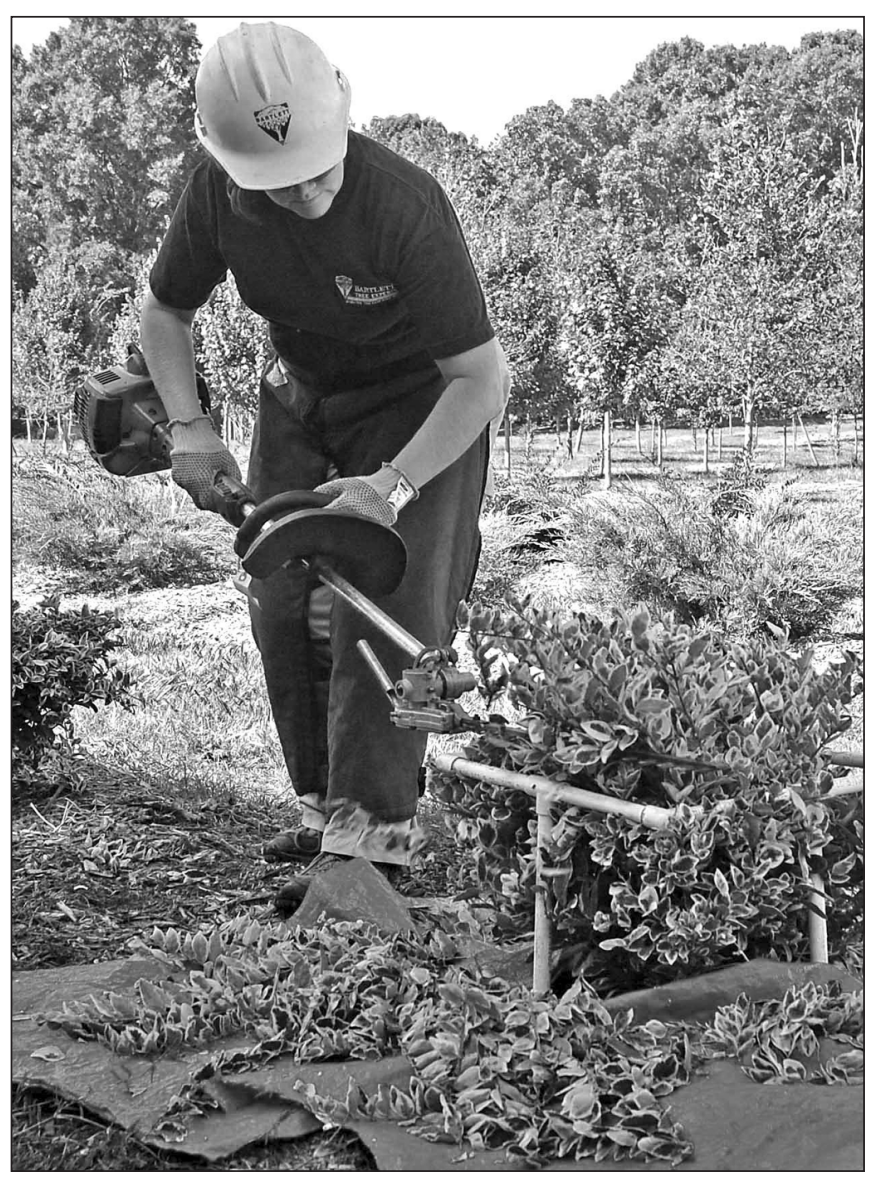

Figure 1. Shearing to the initial uniform size to determine growth biomass using a PVC frame to define the initial plant size and shape.

cal and Fertilizer Corporation, Hanover, PA) at a rate of $6.3 \mathrm{ml}$ per $5 \mathrm{~L}$ (1.3 tsp/1.3 gal) of mix. Application rates were those recommended by the manufacturer from previous unpublished trials (Shawn Bernick, pers comm). Treatments were as follows:

1. 1,000 ppm PBZ [63 $\mathrm{ml}$ of $8 \%$ Paclobutrazol (Cambistat, supplied by Rainbow Treecare Scientific Advancement, St. Louis Park, MN) per $5 \mathrm{~L}$ (4.3 tbsp/1.3 gal) of water].

2. 4,000 ppm PBZ [250 $\mathrm{ml}$ of $8 \%$ Paclobutrazol per $5 \mathrm{~L}$ (1 cup/1.3 gal)].

3. Nonsprayed control.

Plant height and width were measured 3, 6, 12, and 18 weeks after treatment. Plant width was measured in one direction, parallel to the planting row. The initial pruned size of the plants was subtracted from subsequent height and width measurements so that growth data represents new growth after pruning. The biomass of new growth was determined 20 weeks after treatment by reinstalling the PVC frame and shearing all new foliage and twigs that grew beyond the initial cubical dimensions. Leaves and branches were collected and weighted immediately after shearing to determine the total new growth fresh weight.

Statistical analysis of the growth and biomass were conducted on each species independently. Analyses were conducted using ANOVA and Student-Newman-Keuls separation of means tests in $\operatorname{SPSS}(\alpha=0.05)$.

\section{RESULTS}

There was no distortion in growth or obvious reduction in leaf size with either treatment at any time during the trial. However, a white residue was clearly visible on the foliage of the plants treated at the 4000 ppm PBZ rate immediately after application (Figure 2). Minor amounts of residue were visible on the $1000 \mathrm{ppm}$ PBZ rate plants. Residue was not visible on the $1000 \mathrm{ppm}$ rate foliage at the end of trial, but the $4000 \mathrm{ppm}$ rate plants did have some visible residue.

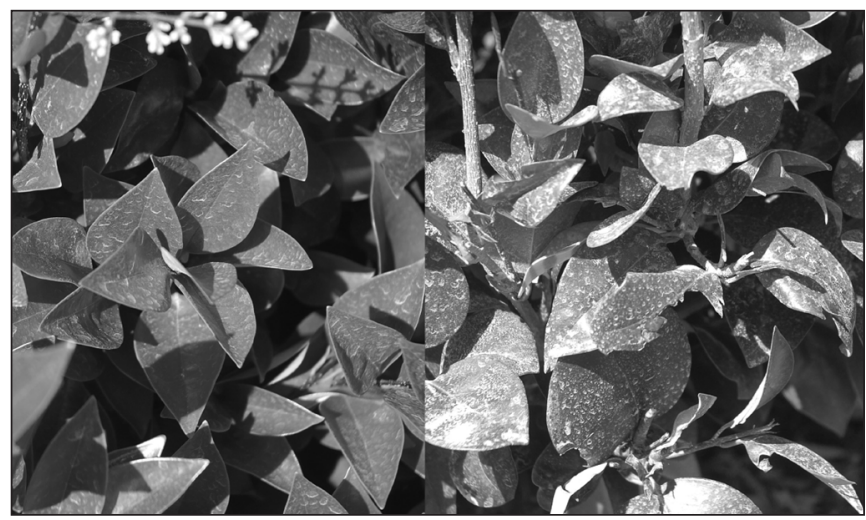

Figure 2. Residual from PBZ spray treatment shortly after applications were made. Left photo is of $1000 \mathrm{ppm}$ application rate and right photo is with the 4000 ppm PBZ rate.

There were significant differences in all measured parameters between the PBZ treated shrubs and the nontreated control plants. Total fresh weight biomass of new leaves and twigs measured 20 weeks after application was significantly less with PBZ treatments as compared to the nontreated control in all species except $L$. sinense (Table 1 ). There were no differences in biomass that can be attributed to the PBZ rate between the $1000 \mathrm{ppm}$ and $4000 \mathrm{ppm}$ treatments in any species tested.

Height and width growth of all shrub species were significantly reduced with PBZ treatment at one or more measurement points (Table 2; Figure 3). For all species combined, 1000 ppm PBZ ap-

Table 1. Mean fresh weight biomass in $\mathrm{Kg}$ (Standard Error) of new growth measure 20 weeks after treatment by shearing shrubs to their pretreatment size and weighing the freshly cut leaves and twigs.

\begin{tabular}{|c|c|c|c|}
\hline Species & $\begin{array}{l}\text { Nontreated Control } \\
\mathrm{Kg} \text { (S.E.) of Biomass }\end{array}$ & $\begin{array}{l}1000 \text { ppm PBZ } \\
\text { Kg (S.E.) of Biomass }\end{array}$ & $\begin{array}{l}4000 \text { ppm PBZ } \\
\text { Kg (S.E.) of Biomass }\end{array}$ \\
\hline Abelia $\times$ grandiflora & $1.39(.17) \mathrm{a}^{*}$ & $0.93(.09) \mathrm{b}$ & $0.68(.09) \mathrm{b}$ \\
\hline Ligustrum japonicum & $4.13(.35) \mathrm{a}$ & $3.13(.17) \mathrm{b}$ & $2.62(.12) \mathrm{b}$ \\
\hline Loropetalum chinensis & $2.16(.08) \mathrm{a}$ & $1.54(.08) b$ & $1.46(.08) \mathrm{b}$ \\
\hline
\end{tabular}

*Means followed by the same letter are not significantly different as determined by ANOVA test and Student-Newman-Keuls separation of mean, $\alpha=0.05$. 
plication reduced height growth by $27 \%$, width growth by $20 \%$; 4000 ppm PBZ application reduced height growth by $40 \%$ and width growth by $33 \%$ as compared to the nontreated control plant.

Abelia $\times$ grandiflora exhibited a significant decrease in height and width growth in weeks 6 and 12 with both PBZ treatments as compared to the control plants (Table 2). Height growth was less, but not significantly at 18 weeks, while width growth remained significantly less throughout the study period. There were significant differences between the two PBZ application rates and

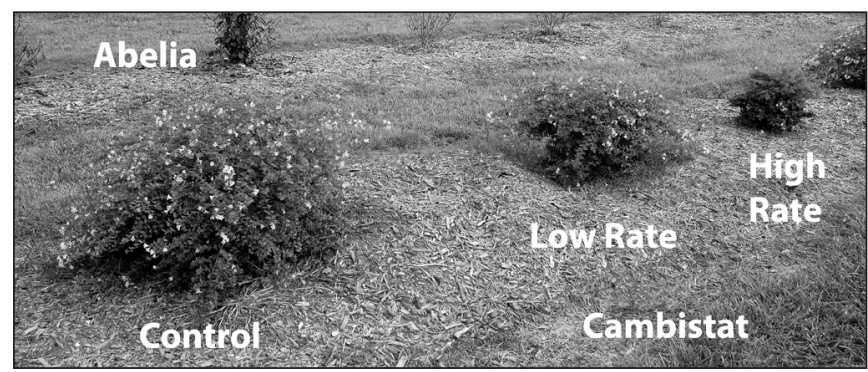

Figure 3. Growth comparison of Abelia 18 weeks after treatment showing from left to right the nontreated control, $1000 \mathrm{ppm}$ (low rate) PBZ (Cambistat) treated plant and the 4000 ppm (high rate) PBZ (Cambistat) treated plant.

the controls in width growth. Differences were as much as $54 \%$ less growth with the $4000 \mathrm{ppm}$ PBZ and $29 \%$ less with the 1000 ppm rate as compared to the nontreated control. It is interesting to note that all of the Abelia shrubs, no matter which treatment was applied, died during winter 2008/2009. The mortality was attributed to the severe shearing done to collect biomass and cold winter temperatures. No other species were affected.

Ligustrum japonicum 'Rotundifolium' was the fastest growing variety tested. It exhibited a significant reduction in height growth at 6,12 , and 18 weeks with the $4000 \mathrm{ppm}$ PBZ and at 6 and 12 weeks for the $1000 \mathrm{ppm}$ rate (Table 2). Width growth was less with the 4000 ppm rate at week 3 and 6 , and week 3 with the $1000 \mathrm{ppm}$ rate. At 12 and 18 weeks, there were no differences in width growth. Height growth was reduced up to $60 \%$ with the $1000 \mathrm{ppm}$ PBZ rate, and up to $69 \%$ with the $4000 \mathrm{ppm}$ rate.

Ligustrum sinense 'Variegatum' was the slowest growing variety tested. It exhibited fewer differences than other species tested (Table 2). Height growth differences between treated and control plants were not significant until week 12 . Width growth was significant at 6 weeks with the $4000 \mathrm{ppm}$ rate. At 18 weeks, there were significant differences in height with both PBZ rates, but no differences among treatments in width growth. Height growth reduction peaked at 12 weeks with a $32 \%$ reduction at the $1000 \mathrm{ppm}$ PBZ rate and $44 \%$ at the $4000 \mathrm{ppm}$ rate.

Loropetalum chinensis had significantly reduced height growth from week 6 to 18 with both PBZ application rates as compared to the control plants (Table 2). At 18 weeks, the high rate of $\mathrm{PBZ}$ provided significantly more growth suppression than the $1000 \mathrm{ppm}$ PBZ rate. Width growth of the treated plants was less at weeks 12 and 18 as compared to the control; there were not differences in growth rate between the two PBZ application rates. Suppression of growth was greatest at week 12 with a $35 \%$ reduction at $1000 \mathrm{ppm}$ PBZ and a $42 \%$ reduction at $4000 \mathrm{ppm} \mathrm{PBZ}$ as compared to the control.

\section{DISCUSSION}

There were large differences in the growth rates among the nontreated shrubs in this trial. In all growth parameters measured, Ligustrum japonicum 'Rotundifolium' > Loropetalum chinensis $>$ Abelia $\times$ grandiflora $>$ Ligustrum sinense 'Variegatum'.

Biomass production, the weight of the debris that is removed after pruning, was greatly reduced on the fastest growing species in this trial by application of PBZ. This is consistent with research done on tree growth (Burch et al. 1996), and should provide considerable savings in the time required for subsequent pruning and debris removal. Only the slowest growing species, L. sinense, did not have significant differences between treated and nontreated plants.

With soil applied growth regulators there are often branches which "escape" treatment, that is, they are not regulated to the

Table 2. Mean new height and width growth which occurred, measured in $\mathrm{cm}$ at 3, 6, 12, and 18 weeks after shearing to a uniform size and treatment with PBZ spray.

\begin{tabular}{|c|c|c|c|c|c|c|c|}
\hline \multirow[t]{2}{*}{ Species } & \multicolumn{4}{|c|}{ Height Growth in $\mathrm{cm}$} & \multicolumn{3}{|c|}{ Width Growth in $\mathrm{cm}$} \\
\hline & $\begin{array}{l}\text { Weeks } \\
\text { after } \\
\text { treatment }\end{array}$ & Control & $\begin{array}{l}1000 \\
\text { ppm PBZ }\end{array}$ & $\begin{array}{l}4000 \\
\text { ppm PBZ }\end{array}$ & Control & $\begin{array}{l}1000 \\
\text { ppm PBZ }\end{array}$ & $\begin{array}{l}4000 \\
\text { ppm PBZ }\end{array}$ \\
\hline Abelia & 3 & 15.8 & 10 & 9.4 & 18 & 13.4 & 12.9 \\
\hline \multirow[t]{3}{*}{$\times$ grandiflora } & 6 & $37.0 \mathrm{a}^{*}$ & $24.3 \mathrm{~b}$ & $18.9 \mathrm{~b}$ & $48.1 \mathrm{a}$ & $34.1 \mathrm{~b}$ & $22.3 \mathrm{c}$ \\
\hline & 12 & $37.2 \mathrm{a}$ & $31.8 \mathrm{ab}$ & $26.3 \mathrm{~b}$ & $96.0 \mathrm{a}$ & $75.1 \mathrm{a}$ & $60.6 \mathrm{~b}$ \\
\hline & 18 & 41 & 39.6 & 33.4 & $102.9 \mathrm{a}$ & $82.5 \mathrm{ab}$ & $63.7 \mathrm{~b}$ \\
\hline Ligustrum & 3 & 4.2 & 1.7 & 1.3 & $6.2 \mathrm{a}$ & $6.0 \mathrm{a}$ & $3.5 \mathrm{~b}$ \\
\hline \multirow{3}{*}{ japonicum } & 6 & $24.2 \mathrm{a}$ & $12.8 \mathrm{~b}$ & $7.4 \mathrm{c}$ & $25.7 \mathrm{a}$ & $18.7 \mathrm{~b}$ & $8.16 \mathrm{c}$ \\
\hline & 12 & $70.8 \mathrm{a}$ & $56.9 \mathrm{~b}$ & $31.9 \mathrm{c}$ & 70.9 & 66.6 & 61.14 \\
\hline & 18 & $116.6 \mathrm{a}$ & $107.9 \mathrm{a}$ & $75.6 \mathrm{~b}$ & 125.7 & 114.8 & 110.5 \\
\hline Ligustrum & 3 & 10.1 & 7.5 & 5.8 & 4.9 & 2.9 & 2.2 \\
\hline \multirow[t]{3}{*}{ sinense } & 6 & 19.4 & 15.2 & 15.1 & $16.9 \mathrm{a}$ & $13.1 \mathrm{a}$ & $7.3 \mathrm{~b}$ \\
\hline & 12 & $32.8 \mathrm{a}$ & $25.4 \mathrm{~b}$ & $24.3 \mathrm{~b}$ & 34.6 & 33.6 & 32.5 \\
\hline & 18 & $56.6 \mathrm{a}$ & $38.1 \mathrm{~b}$ & $31.6 \mathrm{~b}$ & 67.3 & 62.6 & 61.5 \\
\hline Loropetalum & 3 & 13.5 & 13.1 & 10.8 & 20.5 & 17.8 & 16.8 \\
\hline \multirow[t]{2}{*}{ chinensis } & 6 & $28.7 \mathrm{a}$ & $19.2 \mathrm{~b}$ & $18.0 \mathrm{~b}$ & 35.7 & 29.9 & 28.6 \\
\hline & 18 & $83.5 \mathrm{a}$ & $66.1 \mathrm{~b}$ & $51.8 \mathrm{c}$ & $121 \mathrm{a}$ & $102.9 \mathrm{~b}$ & $91.6 \mathrm{~b}$ \\
\hline
\end{tabular}

*Means followed by the same letter are not significantly different as determined by ANOVA test and Student-Newman-Keuls separation of mean, $\alpha=0.05$. Comparisons are within species, across the table, by week of measurement. 
same degree as other branches. In this study of foliar applied PBZ, there were few errant or escape branches observed with any plant species or treatment. The new growth on treated plants was as uniform or more uniform than the growth of the untreated controls.

Abelia $\times$ grandiflora showed the greatest growth suppression 6 weeks after treatment with PBZ. By 18 weeks, there were no differences between either PBZ treatment rate and the control. However, with visual inspection there was noticeably less growth with the $4000 \mathrm{ppm}$ rate. With this species, retreatment should be considered after 12 weeks with either application rate, because the growth rate of the treated plants increased noticeably at that point. The $4000 \mathrm{ppm}$ rate provided more growth suppression on this species. To the eyes of the study's evaluators, this growth suppression was beyond the point of aesthetic desirability. PBZ residue from this high application rate could also present aesthetic problems.

Ligustrum japonicum 'Rotundifolium' treated with PBZ displayed growth suppression 6 weeks after treatment with both application rates. However, at 18 weeks, the $1000 \mathrm{ppm}$ PBZ rate was no longer different than the nontreated control. The suppression continued longer and was more pronounced with the $4000 \mathrm{ppm}$ rate of PBZ. No reapplication would be required at the high rate for 18 weeks of growth suppression. If the $1000 \mathrm{ppm}$ rate was applied, reapplication should be considered between 6 and 12 weeks after the first application when the growth rate of the treated plants accelerated.

Ligustrum sinense 'Variegatum' treated with PBZ had no significant height growth differences until the 12-week measurements. Differences continued in week 18. There were no differences in response between the application rates except for width growth at 6 weeks. Therefore this species appears to respond more slowly to PBZ than the other species tested. Re-application would not be required until after 18 weeks. This species had the lowest overall growth rate.

Loropetalum chinensis treated with PBZ displayed growth differences at 6 weeks and the differences persisted for the remainder of the trial. At 6 and 12 weeks there were no differences between the application rates, however at 18 weeks the higher rate provided more suppression in shrub height growth. Reapplication should be considered at 12 weeks with the $1000 \mathrm{ppm}$ application rate and after 18 weeks with the $4000 \mathrm{ppm}$ rate.

In summary, paclobutrazol was effective at reducing growth on the four shrub species tested. The speed of effectiveness and longevity of this treatment varied with species and application rate. In general, the faster growing the shrub species, the greater benefit and the faster the response from spray applications of PBZ applied immediately after spring pruning. This growth reduction should provide a desirable appearance and less pruning and clean up after pruning when PBZ is applied to fast growing shrubs.

Depending on the length of the growing season and the growth characteristics of the species being treated, one to three spray applications per year may be required to manage growth of shrubs. In areas with short growing seasons, one application may last the entire season, making this a very cost effective service. In areas with longer growing seasons where multiple applications would be required, a soil drench application may be a more appropriate means of application of a plant growth regulator.

While the high rate of PBZ in this trial often provided significantly greater growth control, this does not mean that the high rate is the preferred. The high application rate may, especially in young plants, provide too much reduction in growth which may lead to an unnatural appearance (Figure 3), there may also be aesthetic problems with residue on the leaf surface (Figure 2), and the difference in growth rate between the high and low application rates may not justify the higher cost of the higher application rate. So when selecting application rates, species response; appearance, cost, and, your plant growth goals should all be considered.

Additional research is required to determine the impact of foliar application on growth over several years of application and to compare the differences between soil and foliar application. Since there were large differences in species response to PBZ application, treating untested varieties should be avoided.

\section{LITERATURE CITED}

Aron, Y., S.P. Monselise, R. Goren, and J. Costo. 1985. Chemical control of vegetative growth in citrus trees by paclobutrazol. HortScience 20:96-98.

Bai, S., W. Chaney, and Y. Qi. 2004. Response of cambial and shoot growth in trees treated with paclobutrazol. Journal of Arboriculture 30:137-145.

Burch, P.L., R.H. Wells, and W.N. Kline. 1996. Red Maple and silver maple growth evaluated 10 years after application of paclobutrazol tree growth regulator. Journal of Arboriculture 22:61-66.

Cid, M.C., and M. Caballero. 1993. Control of Canary Islands native shrub species for potted plant use. Acta Horticulturae 337:99-104.

Davis, T.D. 1991. Regulation of tree growth and development with triazole compounds. Journal of Arboriculture 17:167-170.

Edgerton, L.J. 1986. Some effects of Paclobutrazol on growth and fruiting of apple, peach and cherry. Acta Horticulturae 179:467-472.

Joustra, M.K. 1989. Application of growth regulators to ornamental shrubs for use as interior decoration. Acta Horticulturae 251: 359-370.

Looney, N.E., and J.E. McKellar. 1987. Effect of foliar-and soil surface-applied paclobutrazol on vegetative growth and fruit quality of sweet cherries. Journal of the American Society for Horticultural Science 112:71-76.

Martin, C.A., W.P. Sharp, J.M. Ruter, and R.L. Garcia. 1994. Alterations in Leaf Morphology of Two Landscape Shrubs in Response to Disparate Climate and Paclobutrazol. HortScience 29:1321-1325.

Ruter, J.M. 1992. Growth and flowering response of butterfly-bush to paclobutrazol formulation and rate of application. HortScience 27:929.

Welker, E. 1986. Bonzi [paclobutrazol] a new growth regulator for azalea Zierpflanzenbau 16:230-231.

Acknowledgments. We would like to thank: Robert Bartlett Jr. and the F.A. Bartlett Tree Expert Co. for their support of this research. Shawn Bernick and Jim Zwack at Rainbow Treecare Scientific Advancement for the donation of the Cambistat used in this trial and for the guidance they provided. Dr. Glynn Percival of the Bartlett Tree Research Laboratory UK for assistance with the manuscript. 
E. Thomas Smiley (corresponding author)

Arboricultural Researcher

Bartlett Tree Research Laboratory

and

Clemson University

13768 Hamilton $R d$

Charlotte, NC 28278, U.S

tsmiley@bartlettlab.com

Liza Holmes

Research Technician

Bartlett Tree Research Laboratory

13768 Hamilton $R d$

Charlotte NC, 28278, U.S.

Bruce R. Fraedrich

Director of Research

Bartlett Tree Research Laboratory

13768 Hamilton $R d$

Charlotte, NC 28278, U.S.

Résumé. Cette étude a été menée pour déterminer l'effet du Paclobutrazol (PBZ, Cambistat) en vaporisation foliaire sur la croissance de quatre espèces arbustives (Abelia $\times$ grandiflora 'Edward Goucher', Ligustrum japonicum 'Rotundifolium', Ligustrum sinense 'Variegatum', Loropetalum chinensis) dans le Sud-est des États-Unis. Après que les arbustes furent établis, ils ont été taillés à une dimension définie et vaporisés avec 1000 ppm ou 4000 ppm de Paclobutrazol ou encore non traités. Le Paclobutrazol a été efficace pour diminuer la croissance des quatre espèces d'arbustes testés. La biomasse totale de nouvelles feuilles et de tiges récoltées 20 semaines après le traitement était significativement moindre avec le Paclobutrazol comparativement au arbustes du groupe-témoin non traité, et ce pour toutes les espèces à l'exception du L. sinense. Il n'y avait pas de différences dans la biomasse qui pouvait être attribuée au Paclobutrazol à 1000 ppm ou à 4000 ppm pour aucune des espèces. La vitesse de l'efficacité et la longévité de ce traitement variait selon les espèces. En général, le plus vite un arbuste poussait, le plus vite et le plus grand résultat survenaient suite aux vaporisations de Paclobutrazol. Cette réduction de croissance devrait permettre de produire une apparence plus désirable, moins de taille et un nettoyage plus rapide lorsque le Paclobutrazol est appliqué sur des arbustes à croissance rapide.
Zusammenfassung. Diese Studie wurde unternommen, um den Einfluss von Paclobutrazol Blattspray auf das Wachstum von vier Buscharten (Abelia $\times$ grandiflora 'Edward Goucher', Ligustrum japonicum 'Rotundifolium', Ligustrum sinense 'Variegatum', Loropetalum chinensis) in den südöstlichen Vereinigten Staaten zu bestimmen. Nach der Etablierung der Büsche wurden sie auf ein bestimmtes Maß zurückgeschnitten und mit 1000 ppm oder 4000 ppm besprüht und es gab eine unbehandelte Kontrollgruppe. Paclobutrazol zeigte sich effektiv bei der Reduktion von Wachstum bei allen vier getesteten Buscharten. Die totale Biomasse von gesammelten neuen Blättern und Zweigen nach 20 Wochen war deutlich weniger bei den behandelten Büschen als bei der Kontrollgruppe mit Ausnahme von L. sinense. Es gab bei keiner Art einen Unterschied in der Biomasse, der der unterschiedlichen Höhe der Behandlung zuzuschreiben wäre. Die Geschwindigkeit der Effektivität und die anhaltende Wirkung variierten zwischen den Arten. Im Allgemeinen können wir sagen, je schnellwachsender die Art, desto größer der Effekt und schneller der Einfluss von PBZ-Applikationen auf die Pflanze. Wenn PBZ bei schnellwachsenden Buscharten appliziert wird, kann diese Wachstumsreduktion eine wünschenswerte Erscheinung liefern, weniger Rückschnitt und schnelleres Säubern bedeuten.

Resumen. Este estudio fue conducido para determinar los efectos de spray foliares de Paclobutrazol (PBZ, Cambistat) en el crecimiento de cuatro especies de arbustos (Abelia $\times$ grandiflora 'Edward Goucher', Ligustrum japonicum 'Rotundifolium', Ligustrum sinense 'Variegatum', Loropetalum chinensis) en el sureste de los Estados Unidos. Después que los arbustos fueron establecidos, fueron podados para definir tamaño y asperjados con 1000 ppm PBZ, 4000 ppm PBZ o sin tratamiento. Paclobutrazol fue efectivo en la reducción del crecimiento en las cuatro especies de arbustos probados. La biomasa total de nuevas hojas y tallos colectadas 20 semanas después del tratamiento fue significativamente menor con PBZ cuando se compararon a controles no tratados en todas las especies excepto L. sinense. No hubo diferencias en biomasa que pueda ser atribuida a PBZ entre los tratamientos de 1000 ppm y 4000 ppm en cualquier especie tratada. La velocidad de la efectividad y longevidad de este tratamiento varió con las especies. En general, a más rápido crecimiento de las especies de arbustos, hay mayor beneficio y respuesta más rápida de las aplicaciones de sprays de PBZ. Esta reducción del crecimiento debería proveer una apariencia deseable, menos poda y rápida limpieza cuando PBZ es aplicada a arbustos de rápido crecimiento. 